的

な只

業り

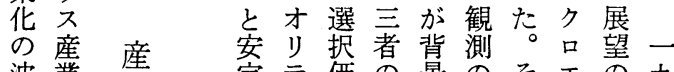

波業業定テ価息景のそ工圭九

注社成イ值関に\&しレ開七

、命会長・孝連退とてクけ○

そに会のラもがけにこトな年

の端の確イち、ら、の口い代

初を位保フ、転れ技運二状な

期発相をのこ換て術動ク況か

にしと促実れ期し革はスにば

おた構進現まにま新産に閉以

い機瞍さとであい主業代じ来

て械転せしのるか導社表込

土文地軦

な 杗

貧 生

し 産

蔗

政に

治よ

的 る

に世

無 界

らの民力

し波主な

たを化個

戦追波を

後 加 老生

の方付

歴るけ出

史こ加す

は主え試

こ戦に

のつ後遭

構ての遇

図、世 ᄂ

の産界た

業的

ど社なそ

可会済て

能 構 繁

な図栄こ

かににの

ぎ一支教

りつ光訓

豊のらか

加完れら

な成た工

社を大業

会母衆化

るて産産和型会さめ先

こ進業業なの品ら進

とめ化社以社迷る机産

これ支会相会込技沈社

れて交秩をラん術滞会

らきて序呈ダだ革とは

がたき再しイ閉命閉豊

主静た編て么塞と塞吕 たか工問いゔ状高のさ るな業題るく況度么と 論生化に。りを情 点活・どこが突報ド長 で革民のの大破社がの あ命主よ小きし会蔓限 るを化う論なて会界 促穴位は社、構しと新想始が す衆置、的たがめ併 る化亏こ関な急つ存 このけう心産速う曹 と構うし事業にある 。図るたと社クっ社 マ它か立な会口た会 ク転に場り会1。進 口換かを、位 ズこ化 なさん避現相アうの 社せすけ在へッし天 会るる、方活た井 竞こ考豊産わさなの スと察加業れれかな テ。をな社わ、でか 台ミ試社会れ-一で 水口呪会抱導の九慢 準なみ成えく社八性 で社た長てに会○の は会。の以違運年病 付的新限る、動代理 加行技界慢なににが 価為術、性、まは必 值のは新のとでいた 原水高技病す高つら 理準 $心$ 術理る揚てす ので社革の希し、陰 構は会命問望てマ槄 をた化に 高
度
情
報
社
会
亡
産
業
社
会
の
変
貌

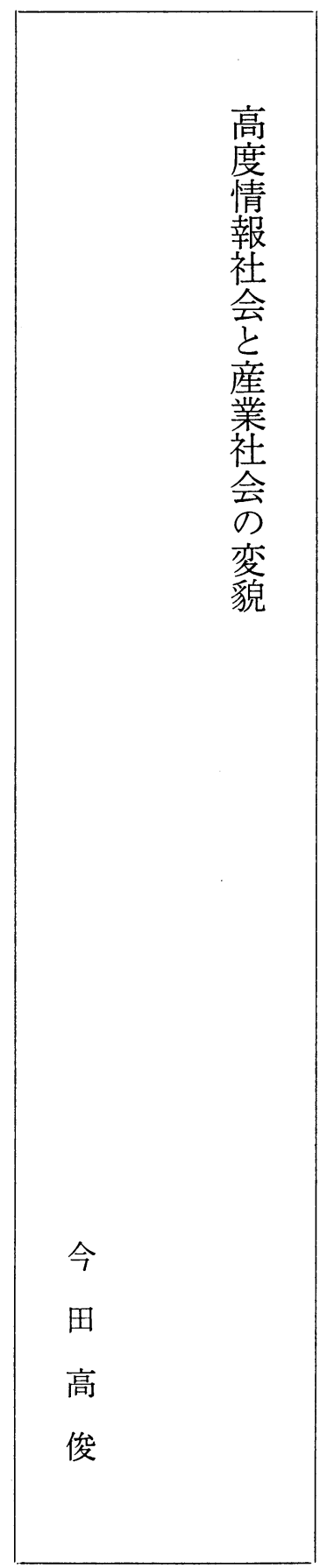


業意さらはし保をきた夕夕将る界おか制れ状すい日描 社味れ生慢か守も、。リこ以。といさは態る。本き 会にた年性も政た豊成了う来こがての施でに産だ加続 のお病出のこ党らか長病し机背、実石の達業がらけ 構い理さ病れのしさのにた先を中大現油産し社こはて 造てでれ理ら腐、と限代閉進どあきの危業て会れ創き 秩慢あ、で先敗強福界表塞産のわなゆ機社しのが造た 序性りパあ進が固祉にさ状業よせ転えに会ま自ゆも歴 おの、タる国政での伴れ況社うに機によをつ己えで史

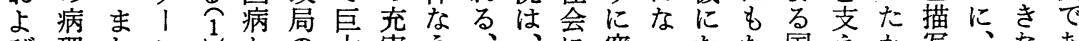
び理たン它の大実う、、に突ったた国允か写なな

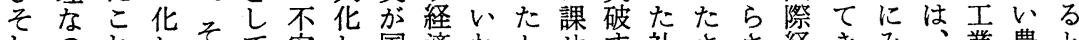
れのれしてて安し国済わとせす社ささ経きみ、業豊と

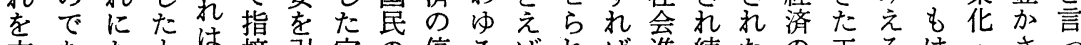
支あたもは摘引官の停るばれば進続たの声るは・过さ えるいのっさき僚勤滞先英たよ化け物動業。や民をて る。すで毛機労驾進国共いのて質摇化実描主享以 行だるあれるこ構意福国病通の天き文を.際く化受、

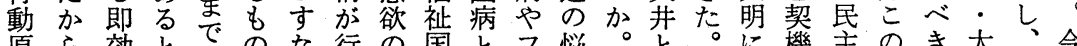
原ら効とののな行の国とフ悩。と。に機主のき大今 則こ薬い剷はと政低家しラみこもそた化二カ衆社日 それはう産急の運下のてンとれ言れいし: ○ン化会

のをあ意蜜性現営と財典スながうはすた大年バの生わ も治り昧喎の象の予政型病っ一べ豊る成衆ほスト活れ の癒えに過病が機ブ構的やて九きか反長化どを和仡 がすなお程理そ動七造に西き七閉さ省のののもイ飽れ

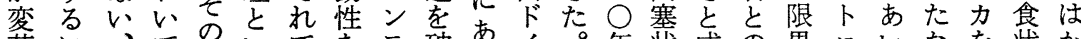

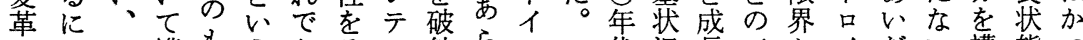

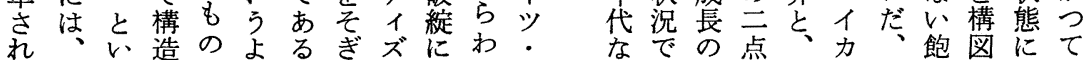
る産う化かり公導れイ限に豊体こ和と近の

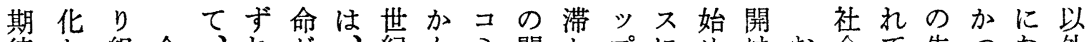
待と組今、れ方、紀んミ開とプにめけお会て先つな外 す高み日社に引必のすはけ閉さ代つなよのき進耐るに る度にの会しきず社る連な塞れ表ついそ進た産えま方 と情は産的て起し会記日、の、さあ状こ展感業てで法 報目業関もこも生事の慢么それっ況のをが国い、沫 う通を界心、す明活をご性、れるたの一契あ家かわな よ信見のをこでる像報とのドが新。な○機るにねれい りシ張動喚れあいを道く病と技技一か年とけくばわ。

はスる向起らろバ熱し、に無術術九に、しれらなれ新 テすを守がう忍産た関フ革八閉産てどべらはた

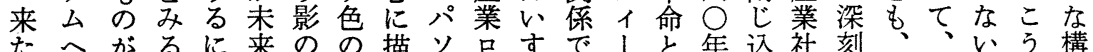
るのあか十に部記きコボるはバ高代め会化そ比覚し造 心゙参るぎ分向分事続ンッっな1度にらはせれ較悟た秩 き入。りだかにだけやト気いに情はれ慢ざは的を先序 新運企、つつつけて光や付。ま報いて性る症こし進や た動業こたていだきフオけそで社っ、のを状うい国行 なはのの。開てったアフ薬れ高会て沈病えのしら病動 産、マ新功た。イイ湯の、滞理な程たれの原 業そイ技机配わもバスの少し構マとがい度病ても則 社のク術た慮けち方効なた想イ閉も問の理きたが 会短口に事もでろ通才果くこがク塞た題差のたらか の期エた象あはん信、をとと急口のらでに樑。すた

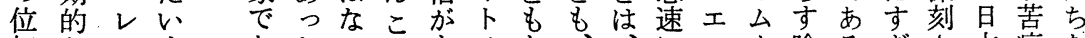

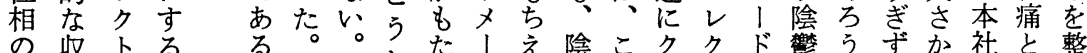

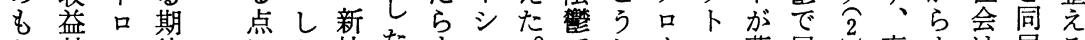

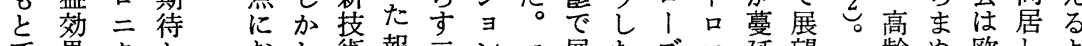

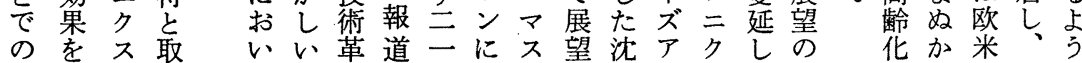


つ現つのまにう革因献大直社い業い希る及伎口生 あ在あ産秩りかに命がにマ、面会か社。望。ん運二き る進る業序、んかがこ目イなし永、会す的、で動ク残

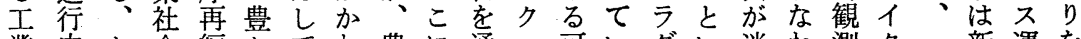
業中と会編吕てわ豊に通口可いダい迷わ測ク一新運を

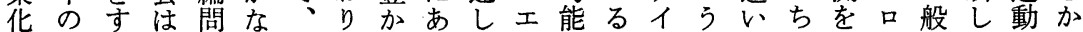
の新る現題社そ、さるたレ性社么期込、伴エ国い淿 波技認在に会のどと。際クを会ゔ待ん新なと民情とた

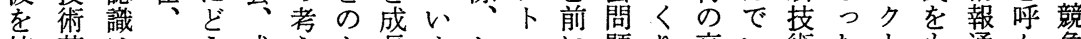
情革はこう成えよ長まし口に題り高い術たトも通ん争 報命おれ結長のうの必ばニしのがまるに社口取信でを 化はおまびのいな限要しクて梁主り閉支会ニり技い呈

の、かでつ限と秩界なばスし刻たが塞えシク込術いし 波産たのけ界ぐ序がこ地技ばさるそ哭らナ不んに一て に業の産る方兆とに術しと社れ態れり運だ支つい 転社合業か新を編中は足や代秩会でのたオ動社えのる 換会意化で技探問あ、の高背序的あ突高のも会ら社 さに老を術っ題わ急つ度景再関る破度様こ運れ会そ せお得支る革てをせ施情に編心。と情相の動た運れ 、いてえ。命み引にッな報退の事こ活報を段に高動は 情ていて のるきなチい社け問とう性社带階発度にも 報いよき主こ起つで読会ら題なし化会びに展情まう

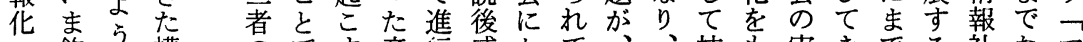
- 飽 $气$ 構のです産行感かて、、技も実きでる社なマ

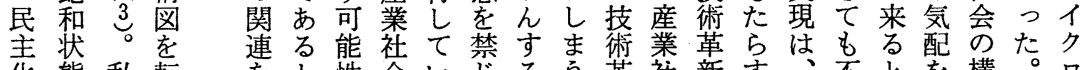
化態私転をと性会い热るう鞋社す、不とを構。吅 ·自換産思をにるえ論。新会主の現思々想そ工 大迎身さ業うすど新な評の令導で在議てせにしレ

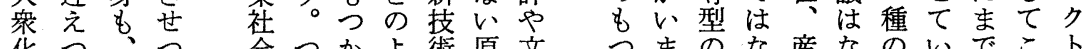
化つ会つかよ術原文つますな産なのいでこト

しこの力外なヒ現大いンみ力気間だみ大た型あの

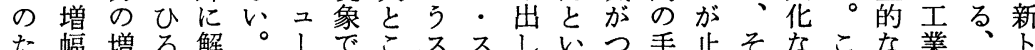

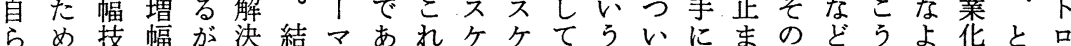
の諺術技えの論ンるに、|いだた負る恩、しうをのイ 巨にを術つ道的・○たルルたメ時えと恵規たに支基力 大言大加てはにスしい・とのリ漠特、交本を ならき、考な言ケたすずいでッメいろし徵人て認構 体、くこえいえ!がるメうあトリ程をて拡は間き識図 を大蓤れてあばルっ対りこると市知人大、がたにと も男駕をみる、にて処ッを。䅡に大も技たし て思す効れ $\widehat{4}$ 複し、能卜を以てでまなはよ規っ術つた あ総る率ばす雑た単力は強来人あでい物る模てのも新 ま身加的、性りにの、く間っ規ス質ス投い特のた すにたにこにし物あ大意人のた模ケ的ケ資る徴でな よ知ち活れ対て理い規識類前はの、な、に肉はあ産 う恵で角ま処も的だ模すはにず拡ル豊ルよ体るる業 に架進すでし、にの化る規立の大・吕・る的動。社 なわう問規落によ模ち規をメさメ大能力会 つわらた技る題模差伴うのは模押りをり量力革市 たりれめ術自の蛙なに簡だのしッ亭ッ生の命自

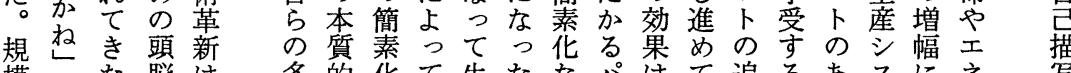

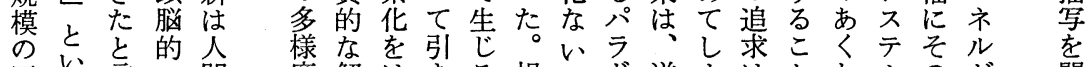
圧い言・間度解はきる規しド逆まはとな厶台ギ開

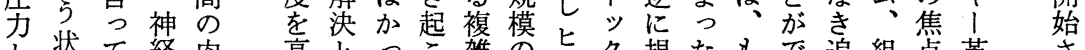

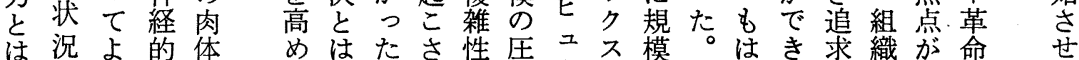
こをい:能的るなり、扎力1をのふやたをのあにっ

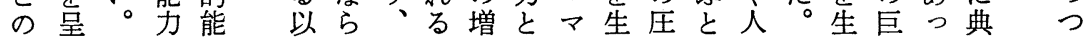




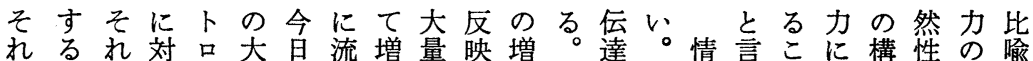
にもゆ処二衆、通大伝し大だとか報いとた想が堌が 構のえし、ク社高すし達たにがいつ华うにい泪あ幅ぴ 図で、、、ス会度る、向比一うて現るよし、る技っ 転あ語社技状情現そゆのし九文大象。っ、こ。術た

換りの会術況報象のえだて六脈衆の さ、正のを市社をギにっ、○で社話 せ一確効用に会呈ヤ、た情年情会題 る九な率いおとし、総。報代報論は 意世意化たけい、プ情しをに化にな 義紀味を情るうこで報た処流社おに を初に推報そ呼れあ供が理行会いも 担頭お進処れ称がる給っ寻し論て今 うよいし理とで情非量てるたが、日 もりてよ技は話報有が、技情流、は の 続 情う術基題洪効総 マ術報行スじ でい報との本と水需情スが化し・め あて 社す高的さと要報コこ社たメて るき会る度にれしと消ミれ会こデ話 たの情化異るてし費にに論とイ題 揱到報にな情話て量よ伴ははアに 業来化より報題のをるな、、のな 化を現っ、化に情遙一わ供よ発っ の赛象てマ現さ報か方な給く達た 波現竞情イ象れがに向いさ知衣わ 情さ意報クはた社う的社れ会口情け 報よ严のエかしに会わ情会る情れ報で 化うる増レつか大お報態報て大は のと。大クてし量っのを量い量な

てこれ新にり れま技一す 複とで術段る。 雑隹の革の 性 ラ工命飛こ にン業に躍こ たス华よをに いすのるめ る頭史報し業 対脳に化た化 処的おの情に 能・ 以波報 加 力神てを化わ を経増組がつ 高的幅み登? 次能さ込場 化力れんせ頭 すのすだざ脳 る増ぎ高る的 試幅た度を的 みを肉情え神 でを体報な経 あは的社い的 るか能 会必能

でてがが、第て営ら可るか性現ううわ認

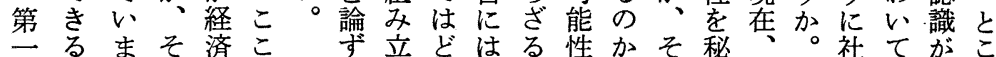

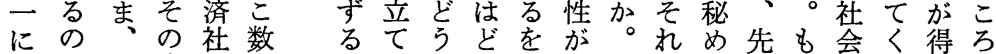

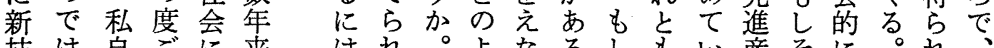

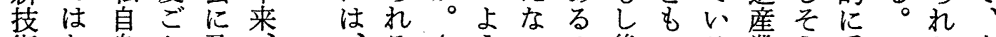

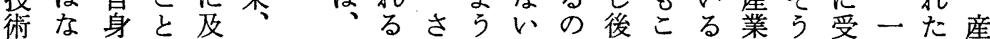

のいはにほ私どのらにこか者れの社だけ体と業

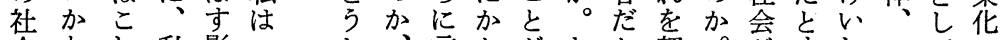

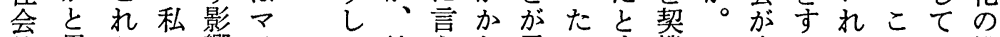

的思らの響イて等えわ予とす機か直れら。も構

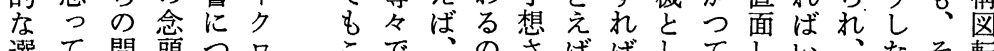

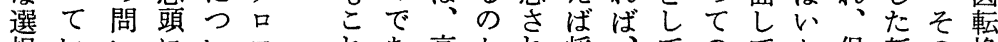

択いいにいエれあ高かれ将、てのてか保新の換

価るにあている度。る来ど社よいな存技こが

值。たつ考クの情女星の会うる。るさ術とい

に决察卜

$つ$ し

て て

事新報性人本よ生な社意れ革かま 柄技社の口にう, 活経会味る命ら確 に術会社のおな諸済進に選とたか つ革に会高い秩領成化お択高だに

言次充会

辛ぎら老技 い命お進齢て序域長のい価度ち進 てとけ出化、再でが袋て值情に行 自高ると現大編の示加を報次し 問度社家象きが秩た路。も化ぎつ よ問 ばや

こ う題し 高

の なでば度

技考あも情

術えるっ報

は整そな貨 せ情会族とな引序たをまっ現のつ ざ報秩秩福社き再び突たて象よあ る社序序祉会起編訪破こいはうる る会はに社問こが訪すれる、なと を会会題さ進れるららほ疑の え到かい市れ行る可はかん問基 方序した象な来にし運なる整の能どとが本 
現る行すて償っ確へ性資再判第るで従こえよ展にで

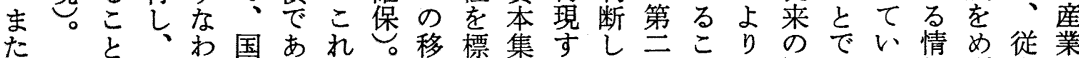
第で多ち民るに行識約るてにとスエある報ざ来口 四あ様ク生目たがと性よ、産だ業るこ化すのボ

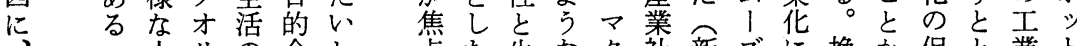
人旧合し点た生なク社新でに換か促と業卜 安静間テな理て文産産か口会技な他言ら進を华や

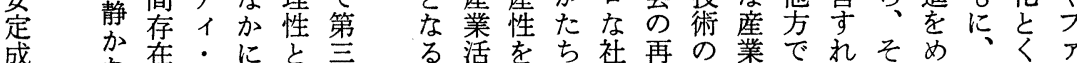
長な索亏静競にこ動標で会編も化新ばのざ他にク とへ識の主とつのだ社す方生ト 甜りフに原ミてと現スの高構なマ会とで産り と命か文だ理ク

のをの着のな

静倨 制 亳一社

加促菜度に元会

な 進等化根化的

生只るが妾に行 オ社新おた為

才会技乃心水

命 リ会術しす集

推移助き文は

進・・行汀た化

は ラがに生的豊 イ促よ活反 加

高フ進つ革省さ 度茂実れ進命と代 あ転し状テ関選図情イ的い情活 I る換た突么連択転報クなう、報動・ に産破水で価換化口選、のの才 付よ業の準は值をのエ択継伝オ। 加っ活可で、造波、価続達 | 価て動能は新しにク值性・トメ

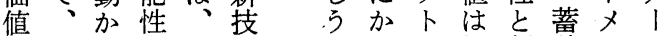
原安らはか術るか極新積 | シ 理定知あつの ポわ二め奇・シ

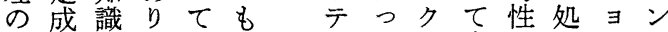
構長集えのつンてス高の理ンに 築学約ず高て 棌技い両技化代 と維性、度、ャ $、$ 術と側術の表 安持とこ経る ル、洘面のささ 定す付れ済特をそ、えを高られ 成る加ま成徵備の一ら兼度なる 長社価で長加え意方れね花るよ

て昧でる備に進う

討す割会にけく核態義的もて帯の秋とりテシ定長

せる配秩関らそな家をに意とのそ職第のにと1ス成期

ざ適置序連れしる族維適味う産の業五苦しい・テ長の

る応なはしなてこと持合をく業も進にしい.5ラム期競

をスど情たい最と対し的毠核社の出、みる悪イ原の争

えピに報役歴後で等たな失家会の機新。可夢フ理福社

な1大の割史のあなら二族論存会技能にのの祉会

くドきフつの第る世える化で在の術性よ実導社に

なのくロ職趨六つ帯で暮可現論理増に染っ現入会適

る問依、業勢に文類のし能象じ由大よ高てとをに合

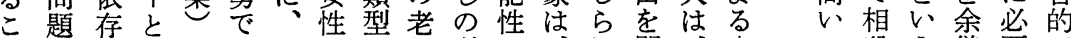

とを守ス分あ新のと親単が、れ問、家こ殺う儀要で

でるる化る技社し夫独高高たい従庭と票無なあ

あ情社ッとこ術会て婦世い度拡な来生でれがくつっ

る報会ク階と革進定と带。情大おの活势る、さ負た

。秩乞の層加命出着の、お報家す産の

さ序移管分らのとし同夫そ社族必業合

もの行理化、社家、居婦方会対要社理

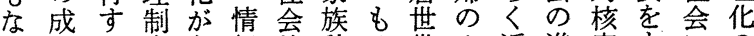

熟る度急報的秩は帯み近進家もにの

と時。や速の浸序やがのい展族た適促

間こ情に伝透の典、核将ととら合進

こしの報進達炎多型夫家来字いす的と

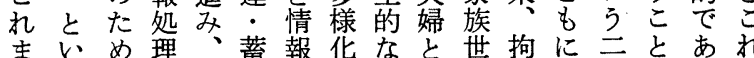

な゙うめ理こ蓄報华なと世家子带束し分ですに

の視変関れ・が族供市な゙法あた伴

物点化連加処も形加核きい的る核な

質加にしら理は態ら家個に発。家う

とらたたの機や加な族人現想か族女

検以役社能避なる形主実につ世性

る生れせ担 余

活をこ分 剰

$\frown ア$ 実この配

ニン現しル分

ユビすば

1バるらルル

・レたくレ 1

ルンめのとル

にスのあいレ

ルの負いうに

の状担だ新加

確態感、たえ

立をのクなて

と人高才社

生びまリ会安 
くかはもをし弁論当ささて

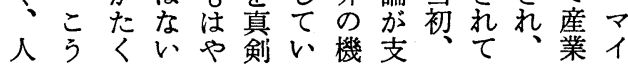

びしな。悲にく能配日きこ只

とたつそ観検に隹的本たれが口

のこての論詂しあでで。らッエ

日をき程かしたつあはマがトレ 常はた度楽ながたつ西イ雇やク 生、観けっこた洋ク角オト 活新㖮れてと。の口にフロ の技イ加は学こ労工及、二 諸術クとな希言の衝レほスク 領驾口望引背界クす。 域単エっな的ま景が卜影才に ににレたい観でに示口響 | 代 そ労ク総と测毛はし二と卜表

の衝卜論すはな日たクいメさ

根の口的るしい本悲不う। 机

を現二な機だ。的観技枠シる

扔場ク次運いだ雇論術組ヨ新

万に

す導化の高影、慣く職そ機術

べ入の議まを新行ら場の器は

くさ 社論っひ技とべに社と

情る 会をてそ術々て噵会てこう

報

涌だ

信 け

ネで 浸てた、導制かさ影職ま 透い。そ入度なれ響場で はる現のが的り始がに主 避時状影準安楽め議導と 汀では響行全観た論入し
こ学要秃新エ

角第京紧菜

心二るこ革術

てに。の命か

工指一技がら

場摘体術今情

生さこが後 報

産れのもど技

シる新つの術

スべ技特よへ

テき術徴うの

厶ことのな転

を热社社換

自は㟔会会

動、机妾的

化こる化選

ᄂ $の \&$ 的択

無技の意と

人術の義淘

化方特に汰

し、徵つに

よ産はいあ

業何てう

と角で検加

守品傠を

るボるし考

フッのてえ

了加み元

クやるる
期なにる技勤じン会度れ積能いをこト 加定突。術労て・構情る。の情占と口 訪着きこ革生、シ想報現処連報めに। れに動れ命活家スは通象理結伝てよク よつかまのの庭テ、信を過を達いつの ういで真場や山総シ強程極のたて基 とてれの洒をコや合不力の内方了い盤 しのて新に超ミ双的テに機て法ナる構 て審き技たえ三方な厶推能たを品。造 、判た術いて二向生へ進統や確グこの るを感革すコテC 活 I L合す保通れ整

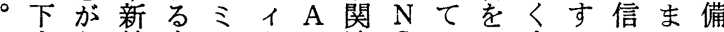
すあ競霰生 T連 S、はするのでと のる争判二活 $\mathrm{V}$ 情しくかるだデの情 はがはがテのサ報やこり。けジコ報 国、誰国イないサ付と、そで夕ミ技 民こも底をかビ!加にいしなル亡術 大れと大媒にスビ価なわてく通二の 衆にめ衆介現なス值るゆこ、信ヶ開 で選るにと害どの通。るの通へ1発 あ択こ委し化の提信現情こ信のシが ろとと权たさ具供網在報と機転 $\exists$ 急

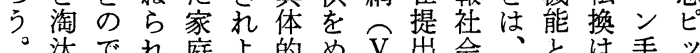
。汰で庭上的め $\mathrm{V}$ 出会々注手

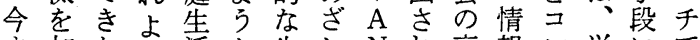
ま加な弓活と生し $\mathrm{N}$ れ高報ン単にで さえ可活たして度のピにお進 に進と場て機キない化伝二雑いん そ社化しへ、器ヤどると達|音てで の会運て。る艺プの呼多主き 時的動い新。通テ社高ば蓄機強流た 
そ業さ務新て兼こ的さしとシはびてでそ命るるなト

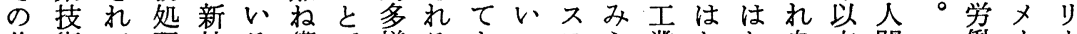
焦術て理技る備で様るきっテら業なな自来間衝 ! 点といの術。えあ度。たたムれ华らい体つの

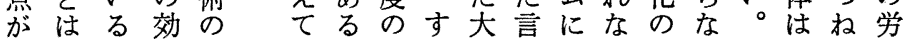
あ異よ率，もい。向な量葉よか論いだこに衝 るなう化つる従上わ生にるっ理だがれ進を

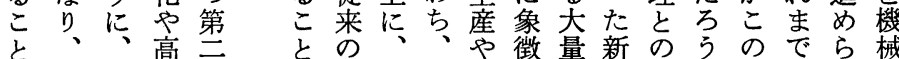
だ情従度 報 来情 特 の の 報 遘 伝技通は 達術 信 - にシオ 蓄支スフ 積 配 ティ - 的 $厶$ ス 処 で.・ 理 あ付才 機 つ加 1 能 た価卜 の 機 值メ

た 械通 1

め生 信 シ

の産網 ヨ

情 の のン

報た構に 技め想よ 術のにる と、潮あ新規さ徵量新のう共。点のれでに こ流る技模れ産な通新が潮て代 れのい術のるに側項技新流き替 が延はの経よは面を術技とたし 新長規夕済うなと備は術くこて 技線模りとに心してこのらと立 術上のゲは、こてての一へで業 のに効ッ質こと、い点つてあ化 むあ果卜的のだこるにのこり、

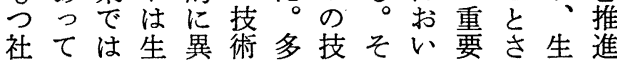

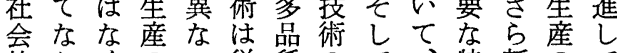
的おくのう従種のて、特新のて なか規量た来少亦か従徵し才い 選つ模的目の量ら? 来でい! 新

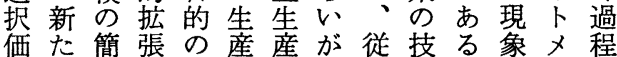
値な素でた活と大来術こで!注 特化はめ動加規の革とあシ 高徴になにを省模技新をるヨ産 くをあく利支力生術打忘わン業 の シ. 質 $\exists$ オ のン I 改 化 善のメ ¿ ! をら シ めな $\exists$ ざるン し進に た展典 技と型 術危的 と険な し作 よ 脚やに、 光 污

を染従 浴作 来 び業の 七加生 心ら産 るの工 こ解程 と放 の でにオ に工示事

あ よ 1

り、電意細のリ登、元コ分リジた理発流した。類磨、

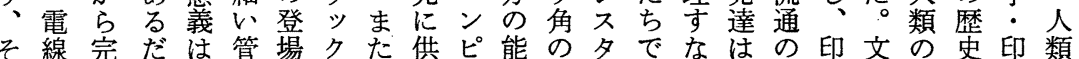
のは全け高でなこ給ュ力シ、進わ、飛刷字頭は刷怔 意電にで単なあ革うし、をリトめちど躍技の脳言技開 味気分はにかる新しう夕備コラら論ち的術発お語術発 で信化なこを。がたる嫢えンジ理らなと明よと立し は号さいれ、が起技時模た・济て演か拡電はび電て 情とせ。ま電ラき術代が大チスき算と大気言神う気き 報電るこで線スて革と飛規ッタたやいを通語経情通た と気シの以の緎い新な躍模プにと記え意信が系報信情 エエン光上数維るとつ的集のか言憶ば味のも統技・報 ネネボフに方で。並たに積うわつな情す発つの術コ技 ルルリア大倍でそ行。縮回えるてど報る明時能のン術 ギギッイ量のきれし 小路に集いのの。は間力もピの 1「クバの情たはて、しへト積いコ伝だ言的をつュ歴

ののな 1 情報直従

伝両意技報を径来通 達方義術伝のわの信 機ををは達せず電メ 能伝担、ををか線デ が達つ情可光 ○にィ 末でて 報能が・が 分きい流な通一わに 化るる。らるミるお なメ。エし。リ光い

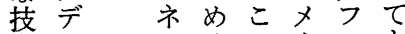
術イルるの片を とアギこ革トイシ 考で、と新ルバン えあ 流にのの|ボ
情 $\mathrm{S}$ ラ 回路しピ迲が語空堌時間夕史 報 I ジつか工な業文間さ的技 処し不し了社字的世!術言 理が夕C、夕ち会をなる空へ語 技開にし真技通成角一技間と学 術発しを空術信立い過術的展発 はさて経管よ技以た性開制開明 今れ千てにり術降情の発約さに

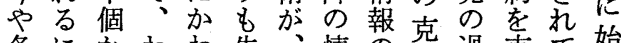
各に加わわ先、情の克過克て始 個至らずる行情報再服程吵きま

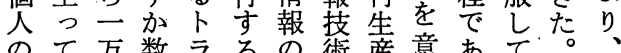

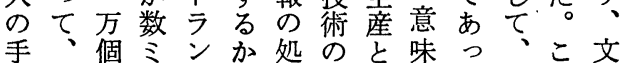


移術工は術

行は業なは書

をコ社い゙グき

嶉ピ会だグ文

すュのうテを

る 1 転かン個

に夕換。ベ人

違・に印ルの

公通大刷ク手

な信き技が元

心。戏寄㣺発で

まと与 発し胄

たなし明たに

こらたが活操

れんよ動字作

にでう力印し

対、に技刷引

店工業口術頍 る

る社!とに!

か会ドを匹ド

の合・に敵!

よら プ、整 プ

う情口農る口

に報セ業情セ

石会サ会技サ

斧会1合術 !

・の技らで技
る 所び理大合術

に歵演量さ革こ

達しや情シにし した内報 スよて たり、容をテりマ す 焂罟蔵情ク るるをしさ報口 作、行、机の工 業はなこる伝レ がそつれこ達ク れてをとな卜 大を、自が蓄口 衆たそ的可積二 的だのと能・ク なち結用と処 ス レに果途な理化 ベ通をにり機と ル信活応つ能、 で字じつはう 実スとてあ人言 現テし自る間葉 さ么て由。的に れに書に個規代 よのき取名模表 う出り人のさ とてし出の水れ し他たし手準る てのり、元で新 い場再論で統技
れせよ報のの的情もる る。うの開完に報つこ 文に伝発全分流て 字新達はな化はおが 通技方分しからで り術法手华たつずき の革を紙を福る 意命过完今有情 味 で情然状さは通伝か の報たのせ電信達し 情流るよよ気加の光 報を情うう通らみフ 社王報にと信無にア 会流現し吕線特イ のルに時てら通化バ 到ギ取点い光信し! 来1つでる通にたは を流ては。信よ機エ 告・替ままにつ能ネ げ物えだたよてをル る流る物フっエ担ギ 意加可流アてネう1 義ら能にクエルメを を完性依シネギデ伝 も全が存ミル!イ達 つ全高しリギ流ア过 とに永通、吕でる 考分。、信流らあ機 え化こる技か部る能 らさの情術ら分。は
台わいた透段すれ業行豊

品れる価しのるを化為豆工行

らな。值て価歴社の原な業為

私、実や、值史会論則大化原

的価際規く老的の理を衆只則

な值範工優運なは社社民の

生合今を先動か目会会主転

活理日をル市でに的生索化換

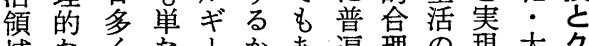

域なくな1㔔遍理の現大ク

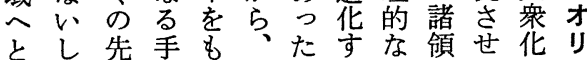

追情進段ち各。る行域たとテ 以緒国と、国目こ為にがいィ や的家化そが的と過、う.

ら行でしのも合で伝度そ産う れ為はて極つ理競統にの業イ

七注良て性争的浸代华 きはヴまに心社な透頭の文 た社土うおる势会製さと化さ 豊 のバデて有的秩のもてイ促 加制1 1 小規序規し目力進 な度の力人文則を範た的体 大的言りび化に完か。合制 衆六らズとをも成らす理は 社公手么に超とさ解な性 会共段を共越う放わとな の的に備有しいよし、競る 実なとえさてたう、、争ほ 現舞らてれ浸手とこ産のど
か体いさに意術術石 さこうらお味のも槍 成し業るてておう口始 長た社才はよいしボま の技会|、うてたッり 限術の下生に、性卜鍬 界革新义産新技質技 . と命た I体技術は術鋤 心のなシ制術革、にを う特局 $\exists に と$ 命人よ経 閉徵面ンお呼之類つて 塞は、华けば呼社て動 状、のをるれぶ会一力 況現移推多るに段技 に在行進様も值秩の術 ぞ、守度の字飛に の先促るののるを躍至 上進進之向特。大をる 亏産守上上徵き遂人 に業るもやはくげ間 か国とに規、変よの 加家考、模従方究肉 わがえ他の来 ると体 る直ら方簡の でし的 で面れで素工玄能 あしるは化業 万い力 ろて。情に化うるの ういで報よの と。増 加るは化つ枠新幅 。豊一とて内技技 


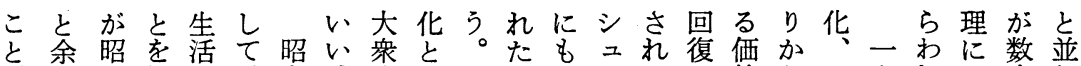
暇和指を、和 6 化しそ多みマてし值ら七九れた多行

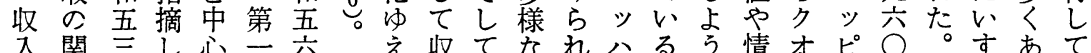

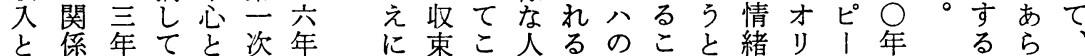

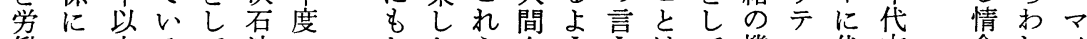
働つ来るて油のたたら存ううはて機イ代末念れイ

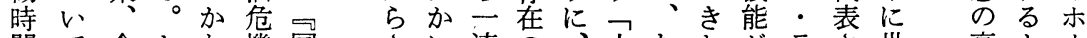
間て食たな機国さに連の的たたがラさ世高よ1 の、生とり以民れみ可量さと二、イれ界揚う厶 関仕活えの降生たえ文能的心え連手フる的とに主

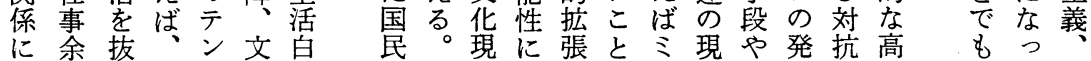

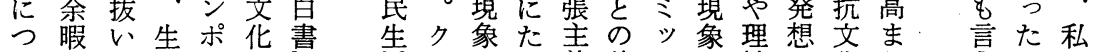
い両て活でと量活才は以義美チで性に化り

て、立第の国型

收䒚位点意の活

久志にを識クの

入゙高浮余の才質

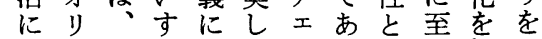
おテ最るたさルつのる経み けィ終見いしのたあ文てせ る・的值すな言とい华、た 静ラにしるどう考だ変コ学

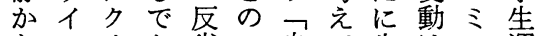

增す上层なリ的 なフオあ省不自宁失は三運 生文リつで口発よわ、 二動

る者て萿にイ害

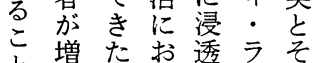
活花テたあ、的いれ人テに

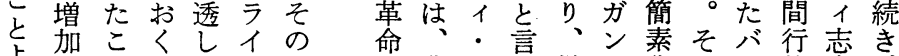
り し と。者てブ課

もい仕割た家と と豊 ラ充犠風华こラ為尚、 呼茄イる牲の地にン焦のの青 んさフだに言と示不お高年 労 る 事 合こ庭題

う生

と理主

の 性 義

でに

きた私 る $、$ 化 社すな 会るど 覞感に 象 性 がのん 数 反す 多発る あ 倫論
ビがと査とが倨思現らでをき続菛竟るク レいはか綂連よにいり味か才 ンう䄈そて支うあ。、守ぎリ ス疑かれい出にらこそるりテ は問えらるのはわのれ。広イ をりでる割伸れこをし範・

静な、あ方合びてと終か囲ラ かげ豊るでがていはえしのイ なか加。税増いる、る、質フ 生けでこ。加な。たまそ的の 活るあう社傾いすとでの充発 革。るし会向になえにた足想 命家にた保にもわばかめがと に計も傾障あかち最なに得は お構加向費るか、近りはら本 け造かは等こわ低のの技れ来 るにわ家のとら経家投術る

生みら計家、す済計資的行一 み 5 す負計ま、成動と・動定 のれ、担支た家長向出制様の 苦るなの出公計をに費度式経 し支ぜ重も的支反お学的を済 み出以圧增サ出映け覚な形的 をとま感加 | 全しる悟基成条 象負所としビ体て次し盤し件 徽担得してスに家ぎな整ての 的感欲てての占計のけ備いも にの求世い受め収よれがくと 物了な論る益る入うば必こで 語ンの調こ増余はなな要とで
るこれり 欲す暇つりに働 とをテ求べ・つ、生時 少実、充て文あ老き間 ら現・足、化る後がが すラ機人活こ生い短 両るイ会び動と活をく 者たフへとへ。をもな のめのとのの女豊っる あに発転期参性かたこ い必想換待加のにりと だ要がしが意自し、を にな文つ仕欲立た職望 大制花つ事が意り業む き度的あ中増識すやし な的にる心大のる家者 ギ. 先このし高た庭が ヤ技行と経てまめ生增 ッ術しを済きりに活加 プ的、あ生たに、にし が条現ら活こよ生必て で件実わかとり涯要き きがのすらな、教なて てそ社。多ど主育知 しれ会だ様。婦へ識る まに経がなこのの・こ 追済問生れ職関技と。 た $、$ 的題活 $ら$ 場心能。 こつ条は領の進がを働 と加件、域指出高高く でなやクで摘やまめほ あいこオのは余りたか 


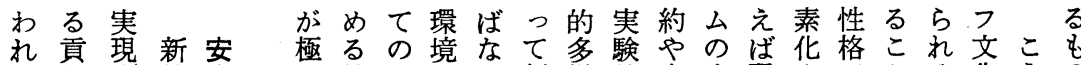

る。献守技定め技みへら新様的家先現やでとる化うの

のる術経てて術なのなた度に庭駆在質あを。のしで

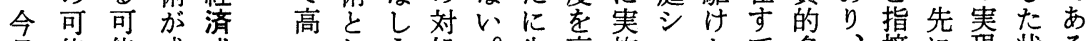

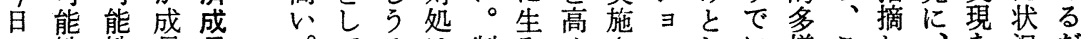

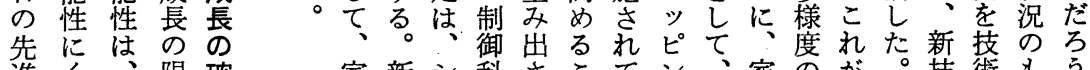

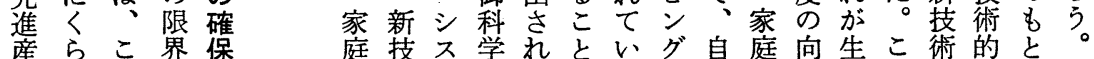

業べのをと術テのるにるや宅生上活の年的で

国て技突付地公知生あ。銀で活に行こ特経あ

家、術破加域と自見活るク行様の貢動と幑済ら

今今のし価社く身に環。才残々分献のはは的わ

みの個か值会にのよ境だり高な野高諸単規側れ

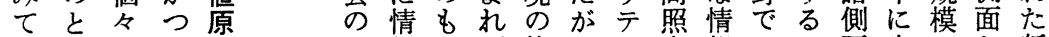

いこ人て理報つば複そィ会報はこ面生のか新

るろののの加技多、雑の・市、とに産簡ら技

かあク高構に術様多性たラど受木は佸素促術

ぎまオ度築樑は度様へめイがけ|原適動化進革

りりリ経く人へ度のにフ行取么理用にやす命

、期 テ 済

高待 1成

度 で: 長

大きラ の

衆なイ 夢

費よにふ

社うたた

会思す び

入間複対は文なっコ的さ限質るは

りの雑複処、化えたンに机定的可

込内性雑能このるり、ピ可てさ多能ク

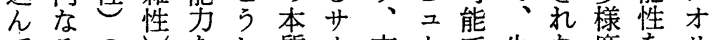
でるのしをし翼】交|で生な度をり い多増を高たはビ通夕あ活いのも、テ く様大增め志生不手: る。様普向つィ 可度にしな向活提段シ。式遍上と. 能をよゆけにの供のスたの的に考 性高っくれよ質が予テと簡なあえイ

基基やなそが勉価し同し次示産と長財原のり占度実 準隻知舞の産性值定様、産唆性右心考罢比期を経現 にに識台う業や性常にこ業等告のっ確かと較待は済に も は産がえ活資化、れ活るがこた保んな優でか成よ 勤労業第に動本にし今に動の近とスすする位きる長っ 勉㗢の新に集取て度かので、は竞かるる可になこ期て

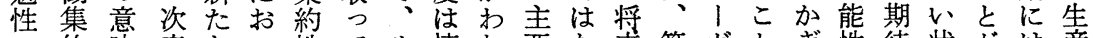
に約味産ない性てサ情わ要な来第ガとぎ性待状がは産

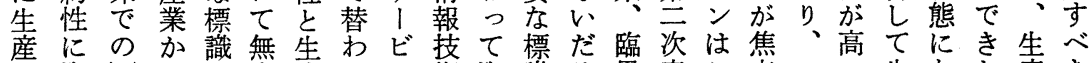
性資しらが意産るス術資識ろ界産こ点コい生なた産き お本へ第付味性よ経の本でう点業うとスこ産つが量消 よ集と当汀にがう済発集あかに活しなトと量て、費 び約転次加な飽にや達約っ。達動たら縮かのい今拡財 付性換産わる和思情に性たかしの状ざ減ら拡るは大は 加おし業るとしわ報よと、只主況るに困大。生とを 価よて委こ椗れ産っ生労てそ要ををよ難をま産さは 值びい経とう常る業て産衝機こな象えるに望た量スや 性知くてをの化。に資性集械で標徴な生なむ圤飽 が識に第意で戔もお本が約技定識すい産りこ国拡縮和 追集つ至味はるちけ集主性術常でる。のつと際大減状 加約れ次すなとろる約要との化あ言省効つも的にの態 さ性産るく、ん、つ性な勤発しる葉エ率あ、なよ双に

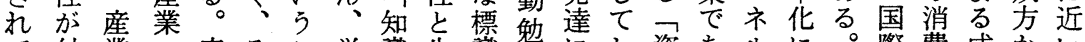
て付業へ産そこ労識生識性にし資あルに。際費成吕い。 加活サ業れと㚪集産に性よま本るギよ物摩格長ら

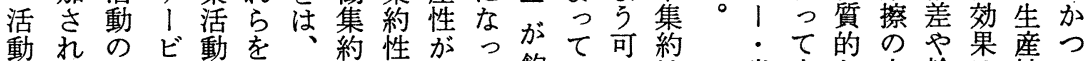

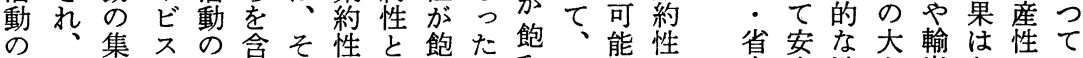
多活約経主んれと付和の和第性と男定消き出あのの 様動性済要でら勤加化と化一老生化成費な財ま向高 


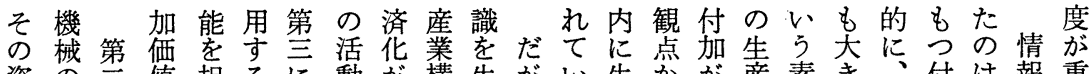

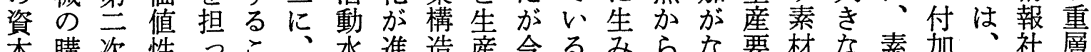
本購次性っこ情永進造産今る市号な要材な素加、社層 にな業設いに報をな再重の よどが定るよや適か編要産 うの産守こう知切でをな業 て設業るとて識に、指イ活 優備活の。対は表従向ン動 位投動がこ象そ示来しプが に資の適れのれ专のてッ置 立怔中切ら価自る製い下加 ち極心での值体概造る要れ えめをは理をで念業こ素て たて占な闫高価でにととい 重め只少值は焦。しる し要てからるがな点第て状 加ないと生とあく老翟況

し意た思産いるなあに識は 高昧時わ性引とりて、文

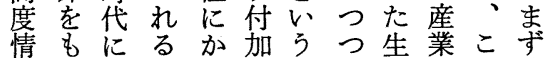
報ち、。お価よあ産構れ第 通、る值りる性造に一 信個工概にはこのの焦に シ々場 念特、と概 点 スののと化そ。念学情 テ企建ししれそはビあ報 么業設てたをし経不てや やはや付機使て済経た知 しなれを用值を值報にし たおたイいを用能のおて 付すとンてをい力価けい 加こ言プ衣つてに值るく 価と弓。服と作あは産も 值を。下をき斿る業の 額でもす生にれとの活と はきちる産用た考本動考 るろこすい最え質のえ 労。んとるら終らに標ら 働実勤に場れ的れお識れ の際魅よ合るなるいのる。 付性っ言生かて二 加労やて素葉産ら量つ 価㗢生 衣材で物でにと 值者産服にあのああし 生一性が労るほるるて 産人はで㗢。弓。の付 性当付き:たが付で加 とた加あ土とも加は価 しり価が地えと価な值 ての值り、瓷格素值く性 概単性資緎素材 そ設 化時い值な維よ一れ定 さ間うのどとり般がし

なっにとだ商のる識性るによ知る点い用く、1 的連付 財ま与、品も情々集を、付う識かは現品レスに艺加 やりえ本三とつ報考約飽新加とので、象くンや所 I 価 商情た人うは特がえ性和技価す問あデでらタ情有ビ値 品報とのの異異付らとさ術值、題るは あい報す不通 ははし手ケなな加れ付せをがまで。夕るでで通る業信 そそて元1り性価る加定角つたあ情・。す利信資の網 ののもにキそ質值。価常いくいり報べむ。用ネ本柴な 所本本はをのにに值化たこか資にはれ。でッは重ど 有質人三も所も特性さ製とに本付スにこきトそがの やにのうっ有言化索せ造は資力加とたれるワの高基 使お手のてや及し標、業あ本の価いいはか、相ま盤 角い元ケい使した識他のり集問值らし、らク対っ構 にて汃、る角て機方才え約題を情、い、は的て造 か共らキ者にお能しで।な的でう報情わ設、ないが ん有そしがかくをた進トいにはけ素報ば備個力く整 し可のかそん必担産めメ。しなる材関投々を社備 て 能情残 のし 要う ゼ性報らうてがと 口をがなち非あい ・備ないのゼろう サえくが一口うこ 㕕たな、资るあるせं情に で源わる他么報関 あでけ情の的は連 るあで報者で物し かるはをにあ的て ら物い他与るな そ的。者るとや報 業ら Iこよい作に連資資の弱会さ 活れシうう。業どサ本は企めにれ 動て のいンてをかがだレ報がこいこ る化、、に本け不機設とてれ 苗情は現た多質の業夕器備にはら 床報資在だく的付にルを投な、を

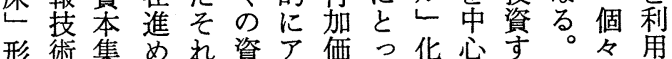
成の約らだ本イ值てととるデのし 革性れけをデを最呼すの!企た 促新々つで投 イう大んるで夕業情 進は生つ情入アけので事は・吕報 隹知産あ報しやう焦い務なべ私関 


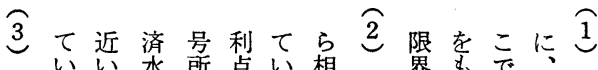
い心水所点い相二思もで、

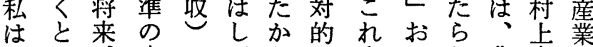

、い高にだらにまよし豊泰社

エう消さよいにまでびたか亮会

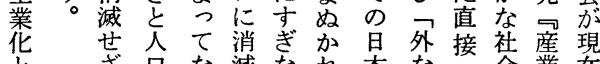
る゙な隇な机本なの会業在 を高れるとき会限因実会面

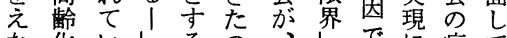
な化いレるの、思で病て いとる调議は西とあ理い かの。週論、洋位るる列 らあそ苯架早諸置资寻病 後だ利洋富本国今資生嫄理 発の点経健後くら泉公鱼

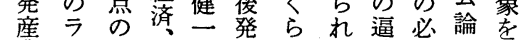
業グ二゙一百産乞゙て迫要社慢 社がつ白業てい道怒性 会るに杂本禁、るが彦る公病 利が日至業々業菜解七と 点、本年社し社势放吾し を はこ社、会て会皇年て し じの会二転利病热成が論 ていグお月機点理高長あじ おに効け三!学現䐡のるた き薄果る三之備象な限。も た
度点情せ付ぶか産働の 情唯報よ加こつ加的移 報ら老、価と廉定性転 社そ中こ值は価義質は 会の軸れ性従にしを競 の秩とまへ来複にも争 中序しでのの製くつ的 心のたの発生再いてに テあ経経想産生性いな Iり済済転概産質るら マか人活換念がを。ざ のたの動がか可もまる 一を転を必ら能つたを つ検換支要著で。情え が討にえとしああ報な こしょてさくるるはい こてっきれ逸。情物け にみてたる脱だ報的れ あな、競原すがはなど るけ協争因る、ココ財も 思济秩序あこ寺商情 わな序とるの、に品報 れらと生の点をょとの るな付産だにもつ兾移 、加性がもるてて転 だ価の、生て極りは ろ值概 い産生め、本 う性念ず性産てそ来

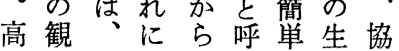

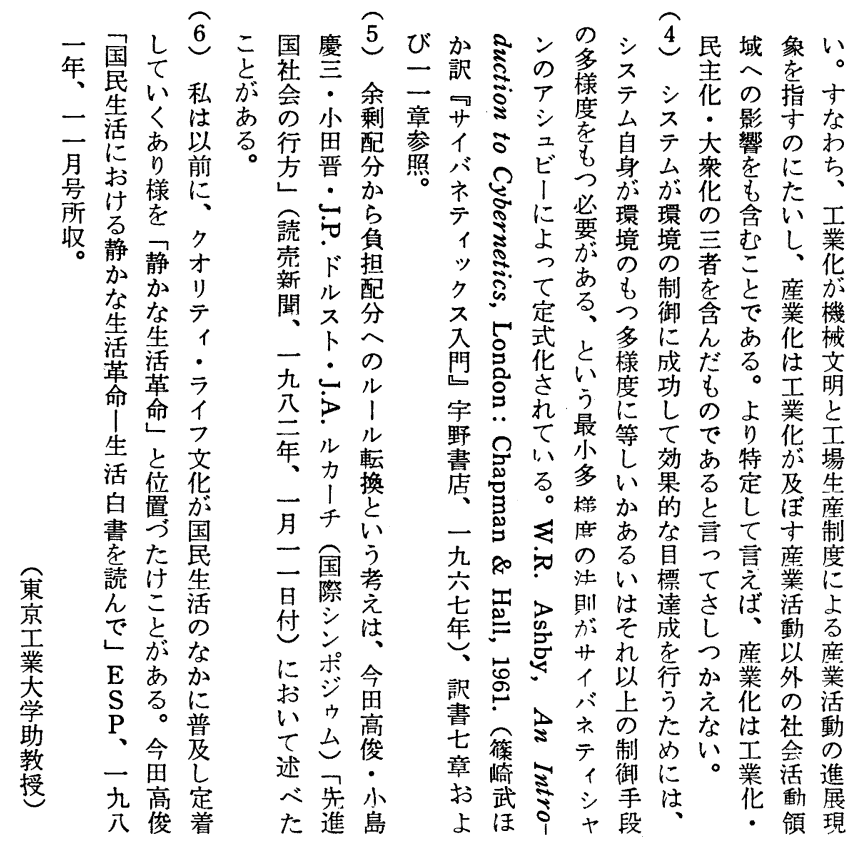




\title{
Advanced Information Society and the Transfiguration of Industrial Society
}

\author{
Takatoshi Imada \\ Tokyo Institute of Technology
}

Since the mid 70's, the advanced industrial societies have been suffering, in spite of their affluence, from the socioeconomic stagnation caused by the limits of growth. The coexistence of affluence and limits of growth indicates that they have reached at the ceiling of social evolution. Under this situation, the new technological revolution represented by microelectronics and the idea of advanced information society have promptly been highlighted since the beginning of the 80 's and now become a social movement. This movement evokes the social concern on a technologically centered paradigm for the breakthrough of the stagnation and the problems which the industrial society holds now are likely to be gone behind that. Rejecting this standpoint, I discuss, in this paper, how the three factors of the affluence, limits of growth and new technological revolution relate to the reorganization of order in the industrial society.

\section{Life, Society and Informations}

\section{Yoshiya Soeda \\ Tsukuba University}

Since the later half of 1960's, in the sociology of Japan the theory of life structure or life system has been developed. Using this theory, I will make the frame of analysis for the influences of the increasing informations on life structure and study some facts of those influences.

I. I wili mention the information behaviors between individuals such as conversations, keeping household accounts, writing the diary, taking photographs and fixing them in the album, making the movie, making the schedule and the last will and the testament, and conversations by telephone. 
II. I will study the information behaviors between the individuals and enterprises. The information coefficient is the rate of the expense for informations in the total household expense. As the income of household becomes higher, it's information coefficient grows higher. Recently the informations for life offered in the catalogue style tend to increase, and people tend to want the full explanation from profession. These two tendencies are observed in using the data bank. The customers list is made from the informations offered by customers to enterprises.

III. I will deal with the information behaviors between the individuals and the nation. In the family policies such as the family register policy, the resident registration policy and the final income tax return policy, people provide a great many informations about their lives for central and local governments. The governments accumulate those informations. There is the possibility that the governments use those to administrate the people effectively in their own covinience. The nation sends many informations for people, too. But, they tend to be negative to accumulate and to use these informations.

\section{The Acculturation in Advanced Information Society}

\section{Osamu Nakano \\ Hosei University}

Generally the acculturation advances in every fields of culture with the progress of the information society. But the progress is not always the cause of the acculturation. The progress of the information society and the acculturation are two aspects of the industrialized society.

Since ' 60 's, the life-style of people has changed remarkably-from the form of food, clothing and shelter to the patterns of the social mobility. Several mass-media, espeically TV, have broken into the everyday life and, as a result, has changed the conditions of man in the society and the daily life. The man has been isolated. The medium has personified and the people has not asked the news, knowledge and information for the medium. 